\title{
PENERAPAN SANKSI PIDANA TERHADAP PEMALSUAN AKTA OTENTIK YANG DILAKUKAN OLEH NOTARIS
}

\author{
Fabryan Nur Muhammad ${ }^{1}$, Yeni Widowaty ${ }^{2}$, Trisno Rahardjo ${ }^{3}$ \\ 1,2,3 Program Studi Hukum, Fakultas Hukum, Universitas Muhammadiyah Yogyakarta, \\ Indonesia \\ Jl. Brawijaya, Tamantiro, Kasihan, Bantul, Yogyakarta \\ E-mail: ${ }^{1}$ fabryan.nur.2013@law.umy.ac.id; ${ }^{2}$ yeniwidowaty@umy.ac.id; \\ ${ }^{3}$ trisnoraharjo@umy.ac.id
}

\section{Info Artikel}

Diajukan: 18-11-2019

Direview: 16-12-2019

Direvisi: $31-12-2019$

Diterima: 31-12-2019

DOI: $10.18196 / \mathrm{mls} .1101$

\begin{abstract}
Abstrak
Notaris merupakan pejabat umum yang berwenang membuat akta otentik, yang mana pembuatan akta otentik tersebut tidak dikhususkan kepada Pejabat umum lainnya. Akta terebut dapat mempunyai fungsi formil (formalitatis causa). Berdasarkan hal tersebut, maka akta otentik dapat diartikan memiliki kekuatan pembuktian yang sempurna. Dalam halnya terjadi suatu tindakkan hukum berupa pemalsuan akta otentik terdapat beberapa sanksi yang dapat dikenakan kepada pihak yang
\end{abstract} melakukannya. Metode yang digunakan di dalam penelitian ini adalah penelitian secara yuridis normatif. Adapun Teknik pengumpulan bahan hukum menggunakan bahan hukum primer dan bahan hukum sekunder. Hasil penelitian adalah (1) Perumusan dari unsur-unsur tindak pidana terhadap pemalsuan akta otentik yang dilakukan oleh notaris adalah bahwa notaris T.E terbukti telah memenuhi unsur subjektif tindak pidana yaitu melakukan kejahatan pemalsuan akta autentik. Berdasarkan perumusan unsur-unsur pidana dari bunyi Pasal 263 KUHP mengenai pemalsuan akta otentik yang dilakukan oleh Notaris tidak bisa diterapkan kepada pelaku yakni Notaris yang memalsu akta otentik. (2) Penerapan sanksi pidana terhadap pemalsuan akta autentik yang dilakukan oleh notaris yaitu dimana notaris terlibat dalam suatu tindak pidana apabila setiap akta yang dibuat Notaris tidak bersumber pada aturan yang telah diatur dalam Undang-Undang Jabatan Notaris (UUJN) 2 Tahun 2014, dan dapat dijatuhi hukuman berdasarkan ketentuan pasal 264 ayat (1) dan 266 ayat (1) KUHP isinya sama yaitu tentang pembuatan akta dengan kesengajaan memakai akta seolah-olah isinya benar.

Kata kunci: akta otentik, pemalsuan, sanksi pidana, tindak pidana.

\section{Pendahuluan.}

Profesi Notaris sangat rawan untuk terkena jeratan hukum. Bukan hanya karena faktor internal yang berasal dari dalam diri Notaris sendiri misalnya kecerobohan, tidak mematuhi prosedur, tidak menjalankan etika profesi dan sebagainya,namun juga dikarenakan adanya faktor internal seperti moral masyarakat dimana Notaris dihadapkan pada dokumen-dukumen palsu padahal dokumen tersebut mengandung konsekuensi hukum bagi pemiliknya. ${ }^{1}$ Undang-Undang Nomor 30 Tahun 2004 tentang Jabatan Notaris mengatur bahwa ketika seorang Notaris dalam menjalankan tugas

\footnotetext{
${ }^{1}$ Pengurus Pusat Ikatan Notaris Indonesia, 2008, Jati Diri Notaris Indonesia Dulu, Sekarang dan Dimasa Datang, Jakarta, PT. Gramedia Pustaka Utama, h. 226.
} 
jabatannya telah melakukan suatu pelanggaran yang menyebabkan penyimpangan dari hukum maka Notaris dapat dijatuhi sanksi yaitu berupa Sanksi Perdata, Administratif/Kode Etik Jabatan Notaris.

Sanksi-sanksi tersebut telah diatur sedemikian rupa baik sebelumnya dan sekarang dalam Undang-Undang Jabatan Notaris terkait Kode Etik Profesi Jabatan Notaris dimana tidak adanya keterangan mengenai sanksi pidana bagi notaris melainkan organisasi Majelis Pengawas Notarislah yang mempunyai kewenangan untuk memberikan hukuman kepada notaris. Demikian dapat disimpulkan bahwa walaupun didalam Undang-undang Jabatan Notaris (UUJN) tidak menyebutkan adanya penerapan sanksi pemidanaan tetapi suatu tindakan hukum terhadap pelanggaran yang dilakukan oleh Notaris tersebut mengandung unsur-unsur pemalsuan atas kesengajaan/kelalaian dalam pembuatan surat/akta autentik yang keterangan di dalam akta isinya palsu maka setelah dijatuhi sanksi administratif/kode etik profesi jabatan notaris dan sanksi keperdataan kemudian dapat ditarik dan dikualifikasikan sebagai suatu tindak pidana yang dilakukan oleh Notaris yang menerangkan adanya bukti keterlibatan secara sengaja melakukan kejahatan pemalsuan akta Autentik. ${ }^{2}$

Hukum Pidana merupakan bagian dari hukum publik yang mengutamakan tekanan dari kepentingan umum pada suatu masyarakat. Adanya suatu pertanggungjawaban pidana harus memenuhi syarat yaitu dengan melihat adanya perbuatan yang dapat dihukum, dengan menyebutkan unsur-unsurnya secara tegas dan berdasarkan undang-undang yang mengatur bahwa perbuatan tersebut telah bertentangan dengan hukum yang merupakan kejahatan pidana, dimana pelaku harus dapat mempertanggungjawabkan sebab-akibat dari perbuatan pidana tersebut. ${ }^{3}$ Penerapan hukum antara Undang-Undang Jabatan Notaris dengan penerapan hukum pidana yang diatur dalam KUHP menjadi tumpang tindih sehingga memberikan suatu ketidakjelasan hukum bagi notaris apabila terjadi kesalahan dalam bertindak berdasarkan tugas dan kewenangannya. Sebenarnya sanksi pidana dapat diterapkan apabila adanya alat bukti suatu pelanggaran hukum yang berkaitan dengan perbuatan pidana sebagai bagian dalam penyelesaian suatu perkara hukum. Sanksi pidana merupakan Ultimum Remedium, yaitu jalan terakhir apabila sanksi atau upaya-upaya hukum lainnya sudah tidak mempan. ${ }^{4}$

Berikut ini contoh kasus yang sering terjadi yang mengikutsertakan notaris terkait pemalsuan keterangan akta autentik, seorang oknum notaris warga Gamping ditahan oleh Jaksa Penuntut Umum Kejati DIY dalam perkara dugaan pemalsuan surat

\footnotetext{
${ }^{2}$ Habib Adjie, 2008, Hukum Notaris Indonesia, Bandung, Refika Aditama, hlm.25

${ }^{3}$ Habib Adjie, "Syarat Akta Otentik", Majalah Renvoi, Nomor 3.39 Vol. IV, Agustus, 2006

${ }^{4}$ Habib Adjie, "Saksi Pidana Notaris", Jurnal Renvoi, Nomor 10 Vol. 22 Tanggal 3 Maret 2005, hlm. 31
} 
atau akta autentik, dengan mengacu pada pasal yang disangka yakni Pasal 263, 264, dan 266 Jo Pasal 55 KUH Pidana dengan ancaman hukuman lebih dari 5 tahun. ${ }^{5}$

Berdasarkan uraian pada latar belakang diatas, maka permasalahan dalam penelitian ini dapat dirumuskan sebagai berikut:

1. Bagaimana perumusan unsur-unsur tindak pidana dalam hal terjadinya pemalsuan akta autentik yang dilakukan oleh notaris?

2. Bagaimana penerapan sanksi pidana terhadap pemalsuan akta autentik yang dilakukan oleh notaris?

\section{Metode Penelitian.}

Kajian tentang Analisis Yuridis Terhadap Pemalsuan Akta Autentik Yang Dilakukan Oleh Notaris ini merupakan jenis penelitian yuridis normatif yaitu metode penelitian hukum yang dilakukan dengan cara meneliti bahan pustaka atau bahan sekunder. Bahan Hukum Sekunder, yaitu bahan-bahan yang erat kaitannya dengan bahan hukum primer dan dapat membantu untuk proses analisis, yaitu: buku-buku ilmiah yang terkait; dokumen-dokumen yang terkait; makalah-makalah seminar yang terkait; jurnal-jurnal dan literatur yang terkait.

Penulisan yang digunakan dengan mengkaji pada pustaka, perundanganundangan, buku hukum, putusan, wawancara dan literature pendukung lainnya yang berkaitan dengan materi penulisan. Sementara penelitian mengambil lokasi di wilayah Pengadilan Negeri Sleman dan Kantor Pengacara M. Zam Zam Wathoni,S.H di Yogyakarta.

Analisis data dilaksanakan secara deskriptif kualitatif, yaitu mengelompokkan data dan menyeleksi data yang diperoleh dari penelitian dengan bertititk tolak pada permasalahan kemudian hasilnya disusun secara sistematis sehingga menjadi data yang konkrit.

a. Kualitatif, metode pengelempokan dan menyeleksi data yang diperoleh dari lapangan menurut kualitas dan kebenarannya, kemudian dihubungkan dengan teoriteori yang diperoleh dari studi kepustakaan, sehingga diperoleh jawaban atas permasalahan yang diajukan.

b. Deskriptif, yaitu metode analisis dengan memilih data yang menggambarkan keadaan sebenarnya di lapangan. Dalam analisis ini menggunakan cara berfikir induktif, yaitu menyimpulkan hasil penelitian dari yang sifatnya khusus ke hal yang sifatnya umum.

\section{Hasil dan Pembahasan.}

Berdasarkan hasil penelitian yang penulis lakukan, diperoleh 1 (satu) putusan yang berkaitan dengan tindak pidana pemalsuan akta autentik yang dilakukan oleh

\footnotetext{
${ }^{5}$ Dilansir dari laman website, http://jogja.tribunnews.com/2017/04/12/notaris-ditahan-setelahdiduga-palsukan-akta-otentik, diakses pada Rabu 12/04/2017 pukul 16.00WIB
} 
notaris yaitu Putusan Pengadilan Negeri Sleman Nomor 184/Pid.B/2017/PN.Smn, sebagai berikut:

\subsection{Putusan Nomor 184/Pid.B/2017/PN.Smn. \\ 3.1.1. Terdakwa}

a. T.E selaku Terdakwa I

b. G selaku Terdakwa II ( diajukan dalam berkas terpisah )

c. S selaku Terdakwa III ( diajukan dalam berkas terpisah )

\subsubsection{Kasus Posisi}

Terdakwa T.E bersama-sama sengan $\mathrm{G}$ dan $\mathrm{S}$ (keduanya diajukan dalam berkas terpisah) pada waktu yang tidak dapat diingat lagi pada tahun 2009 sampai dengan hari Jum'at tanggal 26 Maret 2010 atau setidak-tidaknya pada tahun 2009 sampai dengan tahun 2010 bertempat di Kantor Terdakwa T.E atau setidak-tidaknya pada tempat lain yang masih termasuk dalam daerah hukum Pengadilan Negeri Sleman, telah melakukan, menyuruh melakukan dan yang turut serta melakukan perbuatan membuat surat palsu atau memalsukan surat yang dapat menimbulkan suatu hak, perikatan atau pembebasan hutang atau yang diperuntukkan sebagai bukti daripada sesuatu hal dengan maksud untuk memakai atau menyuruh orang lain memakai surat tersebut seolah-olah isinya benar dan tidak dipalsu, diancam jika pemakaian tersebut dapat menimbulkan kerugian yang dilakukan oleh terdakwa.

\subsubsection{Dakwaan}

Jaksa Penuntut Umum dengan surat dakwaan yang disusun secara campuran, yaitu :
a. Pertama : melanggar Pasal 263 ayat (1) jo Pasal 55 ayat (1) ke-1 KUHP.
b. Kedua : melanggar Pasal 263 ayat (2) KUHP.
c. Ketiga : melanggar Pasal 264 ayat (1) ke-1 jo pasal 55 ayat (1) ke-1 KUHP.
d. Keempat : melanggar pasal 264 ayat (2) KUHP.

Penuntut umum dalam Tuntutan pidananya (requisitor) meminta kepada majelis agar Terdakwa I dijatuhi pidana penjara selama 8 (delapan) bulan dengan dikurangi selama terdakwa berada dalam tahanan, dan dengan perintah terdakwa tetap ditahan.

\subsubsection{Unsur Tindak Pidana terhadap Pemalsuan Akta Autentik yang Dilakukan oleh Notaris}

a. Unsur barang siapa

Bahwa yang dimaksud dengan unsur barangsiapa yang diartikan sebagai subyek hukum atau orang maupun badan hukum, yang merupakan pendukung hak dan kewajiban yang mampu mempertanggungjawabkan akan perbuatannya yang dalam perkara ini menunjuk subjek hukum atau orang yang bernama T.E yang diajukan oleh Jaksa Penuntut Umum di persidangan sebagai terdakwa yang sehat jasmani dan sehat 
rohani dengan kebenaran identitasnya sebagaimana termuat dalam surat dakwaan Jaksa Penuntut Umum yang telah dibenarkan terdakwa sendiri dan telah pula dibenarkan oleh saksi-saksi. Dengan demikian unsur ini telah terbukti.

b. Unsur membuat surat palsu atau memalsukan surat

Berdasarkan sangkalan terdakwa terhadap tanda tangannya dalam SKMHT Nomor 84 Tahun 2010 dikaitkan dengan keterangan saksi-saksi staf dari terdakwa dimana tanda tangan terdakwa dalam akta-akta yang dibuatnya sering tidak sama dan dari hasil pemeriksaan laboratorium forensik atas tanda tangan terdakwa yang tidak dapat disimpulkan dan dikaitkan dengan keterangan dan rangkaian peristiwa yang telah diterangkan oleh para saksi bahwa kertas yang digunakan untuk membuat SKMHT Nomor 84 Tahun 2010 adalah kertas yang didistribusikan di kantor terdakwa, saksi Smenerima perintah untuk menyelesaikan SKMHT 145 Tahun 2009 yang kadaluarsa dan setelah diketik saksi Wanti Mardasih sudah diserahkan kepada terdakwa oleh S dan ketika saksi S tanda tangan dalam SKMHT Nomor 84 Tahun 2010 tersebut tanda tangan para pihak dan terdakwa sudah ada. Saksi Iriani Hartati, SH menerima order notaris dari terdakwa untuk membuat APHT untuk pemasangan Hak Tanggungan dan telah menerima pembayaran dari terdakwa, yang diketahui oleh saksi Darida Noorcahyati yang mengeluarkan uang kas untuk pembayaran adalah rangkaian peristiwa dari pembentukan SKMHT Nomor 84 Tahun 2010 sehingga terbit SHT (Hak Tanggungan Peringkat III) atas kredit HR Purwanto di BPR Danagung Bakti sehingga Majelis mengambil kesimpulan bahwa terdakwa yang membuat SKMHT Nomor 84 Tahun 2010 bahwa sangkalan terdakwa tersebut tidak dapat dibuktikan sehingga haruslah ditolak. Dengan demikian unsur membuat surat palsu atau memalsukan surat telah terpenuhi secara sah dan meyakinkan menurut hukum.

c. Unsur yang dapat menimbulkan suatu hak, perikatan atau pembebanan hutang atau yang diperuntukkan sebagai bukti daripada sesuatu hal.

SKMHT Nomor 84 tanggal 26 Maret 2010 yang dibuat dimana tanda tangan pihak Debitur, Kreditur dan Penjamin palsu tersebut digunakan sebagai syarat terbitnya SHT sebagaimana persyaratan yang ditetapkan di BPN untuk terbitnya sertifikat hak tanggungan. Dengan demikian unsur yang dapat menimbulkan suatu hak, perikatan atau pembebanan hutang atau yang diperuntukkan sebagai bukti daripada sesuatu hal telah terbukti secara sah dan meyakinkan meurut hukum.

d. Unsur dengan maksud untuk memakai atau menyuruh orang lain memakai surat tersebut seolah-olah isinya benar dan tidak dipalsu

Berdasarkan fakta hukum di pengadilan, perbuatan terdakwa bersama-sama dengan saksi $\mathrm{S}$ dan Saksi G membuat SKMHT palsu untuk selanjutnya menyuruh notaris Iriani Hartati, SH memakai surat SKMHT tersebut seolah-olah isinya benar dan tidak dipalsu sebagai dasar pembuatan APHT (Akta Pemasangan Hak Tanggungan) dan SHT (Sertifikat Hak Tanggungan). Dengan demikian unsur dengan maksud untuk 
memakai atau menyuruh orang lain memakai surat tersebut seolah-olah isinya benar dan tidak dipalsu telah terbukti secara sah dan meyakinkan menurut hukum.

e. Unsur terhadap akta-akta otentik

Perbuatan terdakwa yang bersama-sama dengan saksi $\mathrm{S}$ dan saksi G menandatangani SKMHT Nomor 84 Tahun 2010 dimana tanda tangan pihak kreditur, debitur dan penjamin palsu adalah perbuatan membuat surat kuasa memawang hak tanggungan (SKMHT) palsu, dan oleh karena SKMHT adalah akta otentik, maka perbuatan terdakwa termasuk membuat akta otentik palsu. Dengan demikian unsur terhadap akta-akta otentik telah terbukti secara sah dan meyakinkan menurut hukum.

f. Unsur jika pemakaian tersebut dapat menimbulkan kerugian

Berdasarkan putusan Mahkamah Agung Nomor 88 K/Kr/1974 dengan kaidah hukum "kerugian yang mungkin ditimbulkan oleh Pemalsuan Surat tidak harus berupa kerugian materiil, dapat juga berupa kerugian terhadap kepentingan masyarakat seperti dalam hal penggunaan surat yang dipalsukan itu dapat menyulitkan pengusutan suatu perkara. Bahwa SKMHT palsu ini diketahui ketika Agus Mutholib berperkara perdata menggugat Bank BPR Danagung Bakti, sehingga SKMHT ini juga telah menyulitkan pembuktian dalam perkara perdata saksi Agus Mutholib. Dengan demikian perbuatan terdakwa yang bersama-sama membuat SKMHT palsu telah mengakibatkan kerugian immateriil terhadap saksi Agus Mutholib. Berdasarkan hal tersebut unsur jika pemakaian tersebut dapat menimbulkan kerugian telah terbukti secara sah dan meyakinkan menurut hukum.

g. Unsur yang melakukan, menyuruh melakukan dan yang turut serta melakukan

Berdasarkan pledoi penasehat hukum terdakwa yang pada pokoknya menyatakan bahwa terdakwa telah melaporkan Pipit (pegawai BPR Danagung Bakti sebagaimana lampiran pembelaan terdakwa berupa fotocopy surat laporan polisi) yang telah membuat SKMHT Nomor 84 Tahun 2010 tersebut tidak dapat membuktikan bahwa bukan terdakwa yang membuat SKMHT Nomor 84 Tahun 2010 karena berdasarkan keterangan saksi $S$ dihubungkan dengan keterangan saksi Farida Noorcahyati, saksi Notaris Iriani Hartati, saksi Galuh Hapsari dan Ulfa Rahmawati dan Doddy Tatang Efendi Heri yang berkesesuaian satu dengan yang lain sehingga diperoleh petunjuk bahwa terdakwalah yang membuat SKMHT Nomor 84 Tahun 2010, dengan menyuruh saksi S mempersiapkan draft SKMHT-nya dan saksi S serta saksi G disuruh untuk menjadi saksi dalam SKMHT dan telah menandatangani kolom saksi pada SKMHT yang kemudian diberi nomor 84 Tahun 2010 tersebut oleh karena itum pembelaan penasehat hukum terdakwa haruslah dikesampingkan. Berdasarkan hal tersebut, unsur yang melakukan, menyuruh melakukan dan yang turut serta melakukan telah terbukti secara sah dan meyakinkan menurut hukum. 


\subsubsection{Keterangan Terdakwa}

Berikut ringkasan keterangan para terdakwa berdasarkan Putusan Nomor 184/Pid.B/2017/PN.Smn :

T.E, umur 55 tahun, jenis kelamin perempuan, kebangsaan Indonesia, agama islam, Pendidikan terakhir S1.

Berawal pada tanggal 30 Agustus 2007 saksi R. Purwanto mengajukan pinjaman uang di PT BPR Danagung Bakti Jalan Kaliurang KM 5,8 Pandega Satya 26A Kabupaten Sleman sebesar Rp. 800.000.000,- (delapan ratus juta rupiah) berdasarkan Surat Perjanjian Hutang Piutang tertanggal 30 Agustus 2007 Nomor 4502/KUI/08/2007 antara PT BPR Danagung Bakti yang diwakili oleh Tedy Alamsyah, SR (Direktur PT BPR Danagung Bakti) sebagai Kreditur dengan Dr. HR Purwanto, SE., MM., sebagai Debitur dan R. Agus Mutholib, SR.BA sebagai pemilik aset berupa tanah SHM 00864/dadirejo Kabupaten Purworejo yang menjadi jaminan hutang Dr. HR Purwanto, SE., MM., untuk pinjaman selama 6 (enam) bulan, yang dilegalisasi oleh terdakwa selaku notaris yang berkantor kemudian dibuatkan Surat Kuasa Membebani Hak Tanggungan (SKMHT) oleh terdakwa dimana R. Agus Mutholib, SR.BA sebagai pemilik jaminan menandatangani Surat Kuasa Membebani Hak Tanggungan (SKMHT) Nomor 54 tanggal 30 Agustus 2007, selaku pemberi kuasa R. Agus Mutholib, AR.BA dengan persetujuan istrinya Siti Sofiatun, atas nama Dr. HR Purwanto, SE., MM., dan istrinya Hj. Sri Sujiah Purwanto kepada Tedy Alamsyah Sutan Malenggang, SE selaku penerima kuasa.

Pada tanggal 28 Februari 2008, Dr. HR Purwanto, SE., MM. Mengajukan pinjaman baru sebesar Rp. 570.000.000,- (lima ratus tujuh puluh juta rupiah) yang digunakan untuk melunasi pinjaman tanggal 30 Agustus 2007 kepada PT BPR Danagung Bakti dituangkan dalam perjanjian hutang piutang tanggal 28 Februari 2008 Nomor 4676/KUI/02/2008 antara PT BPR Danagung Bakti yang diwakili oleh Tedy Alamsyah, SR (Direktur PT BPR Danagung Bakti) sebagai Kreditur dengan Dr. HR Purwanto, SE., MM., sebagai Debitur dan R. Agus Mutholib, SR.BA sebagai pemilik aset berupa tanah SHM 00864/dadirejo Kabupaten Purworejo yang menjadi jaminan hutang Dr. HR Purwanto, SE., MM., untuk pinjaman selama 6 (enam) bulan, yang dilegalisasi oleh terdakwa selaku notaris yang berkantor kemudian dibuatkan Surat Kuasa Membebani Hak Tanggungan (SKMHT) oleh terdakwa dimana R. Agus Mutholib, SR.BA sebagai pemilik jaminan menandatangani Surat Kuasa Membebani Hak Tanggungan (SKMHT) Nomor 61 tanggal 28 Februari 2008, selaku pemberi kuasa R. Agus Mutholib, AR.BA dengan persetujuan istrinya Siti Sofiatun, atas nama Dr. HR Purwanto, SE., MM., dan istrinya Hj. Sri Sujiah Purwanto kepada Tedy Alamsyah Sutan Malenggang, SE selaku penerima kuasa.

Pada tanggal 28 Februari 2009, Dr. HR Purwanto, SE., MM. Mengajukan pinjaman baru sebesar Rp. 530.000.000,- (lima ratus tiga puluh juta rupiah) yang digunakan untuk melunasi pinjaman tanggal 28 Februari 2008 kepada PT BPR 
Danagung Bakti dituangkan dalam perjanjian hutang piutang tanggal 28 Februari 2009 Nomor 14.229/KUB/02/2009 antara PT BPR Danagung Bakti yang diwakili oleh Tedy Alamsyah, SR (Direktur PT BPR Danagung Bakti) sebagai Kreditur dengan Dr. HR Purwanto, SE., MM., sebagai Debitur dan R. Agus Mutholib, SR.BA sebagai pemilik aset berupa tanah SHM 00864/dadirejo Kabupaten Purworejo yang menjadi jaminan hutang Dr. HR Purwanto, SE., MM., untuk pinjaman selama 6 (enam) bulan, yang dilegalisasi oleh terdakwa selaku notaris yang berkantor kemudian dibuatkan Surat Kuasa Membebani Hak Tanggungan (SKMHT) oleh terdakwa dimana R. Agus Mutholib, SR.BA sebagai pemilik jaminan menandatangani Surat Kuasa Membebani Hak Tanggungan (SKMHT) Nomor 145 tanggal 28 Februari 2009, selaku pemberi kuasa R. Agus Mutholib, AR.BA dengan persetujuan istrinya Siti Sofiatun, atas nama Dr. HR Purwanto, SE., MM., dan istrinya Hj. Sri Sujiah Purwanto kepada Tedy Alamsyah Sutan Malenggang, SE selaku penerima kuasa.Untuk biaya order notaris tanggal 28 Februari 2009 yaitu perjanjian kredit, SKMHT dan pemasangan hak tanggungan peringkat ketiga (III) sebesar Rp. 3.365.450,- (tiga juta tiga ratus enam puluh lima ribu empat ratus lima puluh rupiah) telah dibayarkan ke terdakwa oleh pihak PT BPR Danagung Bakti dengan cara ditransfer ke rekening terdakwa No. Rek. 0200030004843 pada tanggal 28 Februari 2009.

Guna pemasangan hak tanggungan sehubungan jaminan hutang Dr. HR Purwanto, SE., MM., kepada PT BPR Danagung Bakti berupa SHM 00864/dadirejo Kabupaten Purworejo yang lokasinya berada di Kabupaten Purworejo, maka pembuatan Akta Pembebanan Hak Tanggungan (APHT) tingkat pertama SKMHT Nomor 54 tanggal 30 Agustus 2007 dan APHT tingkat kedua atas SKMHT Nomor 61 tanggal 28 Februari 2008 sebagai syarat terbitnya Sertifikat Hak Tanggungan (SHT), oleh terdakwa prosesnya dimintakan kepada Notaris Iriani Hartati, SH yang berkantor di Purworejo dengan cara mengirimkan SKMHT Nomor 54 tanggal 30 Agustus 207 dan SKMHT Nomor 61 tanggal 28 Februari 2008.

Terhadap perjanjian hutang piutang tanggal 30 Agustus 2007 dan 28 Februari 2008 telah diterbitkan Sertifikat Hak Tanggungan (SHT) oleh Kantor Pertanahan Kabupaten Purworejo sebagai bukti bahwa obyek tanah SHM 00864/dadirejo Kabupaten Purworejo telah dibebani hak tanggungan. Terhadap SKMHT Nomor 145 tanggal 28 Februari 2009 atas perjanjian hutang piutang tanggal 28 Februari 2009 Nomor 14.229/KUB/02/2009 pihak PT BPR Danagung Bakti juga meminta order kepada terdakwa selaku notaris untuk pemasangan Hak Tanggungan sebagaimana Ornot (HT III) pada tanggal 28 Februari 2009. Terhadap order notaris tanggal 28 Februari 2009 tersebut ternyata tidak diproseskan oleh terdakwa selaku notaris, sehingga SKMHT Nomor 145 tanggal 28 Februari 2009 menjadi batal demi hukum.

Sekitar enam/tujuh bulan sejak dimintakan order kepada terdakwa selaku notaris oleh PT BPR Danagung Bakti, sertifikat Hak Tanggungan peringkat III atas perjanjian hutang piutang tanggal 28 Februari 2009 Nomor 14.229/KUB/02/2009 belum juga terbit dan asli SHM 00864/dadirejo Kab. Purworejo juga belum kembali kepada PT BPR 
Danagung Bakti sehingga jaminan hutang piutang tersebut berupa SHM 00864/dadirejo Kab. Purworejo menjadi tidak dibebani hak tanggungan, maka saksi Marinda Kurniasari sebagai Admin Bank PT BPR Danagung Bakti dan Hisni S. Widiyati, SE bagian Sistem Pengawas Internal (SPI) Bank PT BPR Danagung Bakti mendatangi kantor notaris terdakwa guna menanyakan tentang SHT peringkat III dan asli SHM 00864/dadirejo Kab. Purworejo.

Sekitar dua atau tiga bulan kemudian yaitu sekitar bulan Maret 2010 saksi Marinda dan saksi Hisni melalui telepon menghubungi lagi kantor notaris terdakwa menanyakan kembali SHT peringkat III dan asli SHM 00864/dadirejo Kab. Purworejo, saat itu diterima dan dijawab oleh saksi S "belum jadi dan sedang dalam proses" setelah itu saksi S dipanggil masuk ke ruangan terdakwa dan dalam ruangan terdakwa saksi S melihat draft SKMHT nomor 84 tanggal 26 Maret 2010 yang berada di meja terdakwa telah ada tandatangan para pihak yaitu R. Agus Mutholib, AR.BA, Siti Sofiatun, Dr. HR Purwanto, SE., MM., Hj. Sri Sujiah Purwanto dan Tedy Alamsyah, serta tandatangan terdakwa selaku Notaris, dan saat itu saksi S disuruh terdakwa untuk tandatangan pada kolom saksi An. S, kemudian terdakwa juga meminta saksi G untuk menandatangani pada kolom tandatangan $\mathrm{G}$ sebagai saksi.

Setelah draft SKMHT Nomor 84 tanggal 26 Maret 2010 tersebut lengkap ada tandatangan para pihak yang dipalsukan selanjutnya terdakwa menyuruh saksi $\mathrm{S}$ memberikan Nomor Register 84 tanggal 26 Maret 2010 yang dikerjakan oleh saksi S dengan menggunakan mesin ketik. Terdakwa mengetahui untuk proses/prosedur penerbitan SKMHT baru apabila SKMHT Nomor 145 tanggal 28 Februari 2009 tidak berlaku lagi/daluwarsa/batal demi hukum yaitu harus ada kehendak dari para pihak untuk memperbarui atau membuat SKMHT baru dengan menghadirkan pihak-pihak yang berkepentingan.

Proses/prosedur yang seharusnya tersebut tidak dilakukan oleh terdakwa selaku notaris, dimana para pihak tidak pernah dipanggil dan tidak pernah hadir untuk memperbarui SKMHT Nomor 145 tanggal 28 Februari 2009 yang telah daluwarsa/batal demi hukum tersebut, namun justru terdakwa menerbitkan SKMHT baru Nomor 84 tanggal 26 Maret 2010 yang merupakan SKMHT palsu karena tandatangan para pihak pada SKMHT Nomor 84 tanggal 26 Maret 2010 dipalsukan oleh terdakwa pada kolom tandatangan.

\subsubsection{Putusan}

Memperhatikan ketetuan Pasal 264 ayat (1) ke-1 KUHP jo Pasal 55 ayat (1) ke-1 KUHP dan ketentuan hukum dan peraturan perundang-undangan lain yang bersangkutan:

\section{Mengadili}

a. Menyatakan terdakwa T.E telah terbukti secara sah dan meyakinkan bersalah melakukan tindak pidana "Turut Serta Melakukan Pemalsuan Surat Autentik" 
b. Menjatuhkan pidana terhadap terdakwa berupa pidana penjara selama 4 (empat) bulan

c. Menetapkan masa penahanan yang telah dijalani oleh terdakwa dikurangkan seluruhnya dari pidana yang dijatuhkan

d. Menetapkan agar terdakwa tetap berada dalam tahanan

e. Menyatakan barang bukti

\subsection{Analisis}

Di ruang lingkup Notaris kita mengenal adagium bahwa "Setiap orang yang datang menghadap Notaris telah benar berkata. Sehingga benar berkata berbanding lurus dengan berkata benar". Jika benar berkata, tidak berbanding lurus dengan berkata benar yang artinya suatu kebohongan atau memberikan keterangan palsu, maka hal itu menjadi tanggungjawab yang bersangkutan. Jika hal seperti itu terjadi, maka seringkali Notaris dilaporkan kepada pihak yang berwajib dalam hal ini adalah Aparat Kepolisian. Dalam pemeriksaan Notaris dicercar dengan berbagai pertanyaan yang intinya Notaris digiring sebagai pihak yang membuat keterangan palsu.

Penjatuhan sanksi pidana terhadap notaris dapat dilakukan sepanjang batasanbatasan sebagaimana tersebut diatas dilanggar, artinya disamping memenuhi rumusan pelanggaran yang disebutkan dalam Undang-Undang Jabatan Notaris (UUJN) dan Kode Etik profesi Jabatan Notaris yang juga harus memenuhi rumusan dalam Kitab UndangUndang Hukum Pidana (KUHP). Dengan adanya penjelasan tersebut di atas notaris bisa saja dihukum pidana, jika dapat dibuktikan di pengadilan, bahwa secara sengaja Notaris bersama-sama dengan para pihak/penghadap untuk membuat akta dengan maksud dan tujuan untuk menguntungkan pihak atau penghadap dengan cara merugikan pihak penghadap yang lain. Jika hal ini terbukti maka pihak penghadap yang merugikan pihak lain beserta Notaris tersebut wajib dihukum.

Notaris dalam melaksanakan jabatannya sebagai pejabat umum yang membuat akta otentik sebenarnya berada diantara mungkin/tidak mungkin melakukan pemalsuan akta dengan pihak yang menghadap untuk meminta dibuatkan aktanya. Dikarenakan apabila seorang notaris selaku pejabat umum tidak lagi menjunjung tinggi tentang Etika profesinya/tidak lain menyimpang dari peraturan hukum Undang-Undang Jabatan Notaris (UUJN)/dengan alasan ingin menguntungkan salah satu pihak tersebut untuk ikut peran serta membantu para pihak lainnya dan sebaliknya sehingga lahirlah akta yang mengandung keterangan palsu.

Akibat hukum terhadap pemalsuan akta otentik yang dilakukan oleh notaris yaitu pada dasarnya terjadi suatu perkara dimana pejabat umum yaitu notaris telah mencari-cari keuntungan serta menyalahgunakan kewenangan yang telah diatur dalam peraturan Undang-Undang Jabatan Notaris dan seorang klien/penghadap lainnya merasa dirugikan atas dibuatnya suatu akta yang mengandung keterangan palsu oleh notaris. 
Maka mengenai pembatalan terhadap akta tersebut adalah menjadi kewenangan hakim perdata, yakni dengan mengajukan gugatan secara perdata ke pengadilan.

Apabila dalam persidangan dimintakan pembatalan terhadap akta oleh pihak yang dirugikan (pihak korban) maka akta notaris tersebut dapat dibatalkan oleh hakim perdata apabila ada bukti lawan. Pembatalan akta dapat menimbulkan keadaan yang tidak pasti, oleh karena itu Undang-Undang memberikan waktu terbatas dalam hal menuntut dimana oleh Undang-undang dapat dilakukan pembatalan apabila hendak melindungi seseorang terhadap dirinya sendiri. Dengan demikian dalam suatu putusan oleh hakim perdata selama tidak dimintakan pembatalan maka perbuatan hukum/perjanjian yang tercantum dalam akta tersebut akan tetap berlaku atau sah. Setelah adanya putusan hakim perdata yang berkekuatan hukum tetap atas gugatan penuntutan pembatalan akta tersebut, maka akta itu tidak lagi mempunyai kekuatan hukum sebagai alat bukti yang otentik karena mengandung cacat secara yuridis/cacat hukum, maka dalam amar putusannya hakim perdata akan menyatakan bahwa akta tersebut batal demi hukum. Berlakunya pembatalan akta tersebut adalah berlaku surut yakni sejak perbuatan hukum/perjanjian itu dibuat.

Pembatalan terhadap suatu akta otentik dapat juga dilakukan oleh notaris apabila para pihak/penghadap menyadari tentang adanya kekeliruan atau kesalahan yang telah dituangkan dalam akta tersebut, sehingga dapat membuat keraguan terhadap kesepakatan/perjanjian dari para pihak/penghadap, maka akta tersebut dapat dibatalkan oleh notaris. Apabila notaris terseret dalam perkara pemalsuan akta yang menjadi aktor intelektualnya atau notaris turut serta ikut melakukan pemalsuan surat yang bisa dikategorikan dalam perbuatan tindak pidana tersebut maka secara yuridis tidak dapat ditolelir bukan hanya berdasarkan ketentuan pidana saja, tetapi juga oleh Peraturan KUHPerdata serta Peraturan Undang-Undang Jabatan Notaris (UUJN).

\section{Simpulan.}

\subsection{Simpulan}

a. Perumusan dari unsur-unsur tindak pidana terhadap pemalsuan akta otentik yang dilakukan oleh notaris adalah bahwa notaris T.E terbukti telah memenuhi unsur subjektif tindak pidana yaitu melakukan kejahatan pemalsuan akta autentik. Berdasarkan perumusan unsur-unsur pidana dari bunyi Pasal 263 KUHP mengenai pemalsuan akta otentik yang dilakukan oleh Notaris tidak bisa diterapkan kepada pelaku yakni Notaris yang memalsu akta otentik. Akan tetapi Notaris tersebut dapat dikenakan sanksi dari Pasal 264 KUHP, sebab Pasal 264 KUHP merupakan Pemalsuan surat yang diperberat dikarenakan obyek pemalsuan ini mengandung nilai kepercayaan yang tinggi. Sehingga semua unsur yang membedakan antara Pasal 263 dengan Pasal 264 KUHP hanya terletak pada adanya obyek pemalsuan yaitu "Macam surat dan surat yang mengandung kepercayaan yang lebih besar akan kebenaran isinya" Sedangkan pelaku yang menyuruh notaris membuat surat/akta palsu dapat dikenakan sanksi pidana Pasal 266 KUHP. 
b. Penerapan sanksi pidana terhadap pemalsuan akta autentik yang dilakukan oleh notaris yaitu dimana notaris terlibat dalam suatu tindak pidana apabila setiap akta yang dibuat Notaris tidak bersumber pada aturan yang telah diatur dalam UndangUndang Jabatan Notaris (UUJN) serta apabila terdapat Notaris yang "nakal" dan berbuat curang dalam membuat akta maka notaris tersebut dapat dijatuhi hukuman, akan tetapi mekanisme yang perlu ditempuh adalah harus menjalani tiga (3) ketentuan yaitu berdasarkan ketentuan yang pertama Menurut Peraturan UndangUndang Nomor 30 Tahun 2004 tentang Jabatan Notaris dapat diterapkan tentang pemecatan jabatan/Notaris diberhentikan dari jabatannya oleh Pemerintah/Menteri dikarenakan telah melalaikan/melanggar Kode Etik Profesi Notaris dalam menjalankan tugasnya sebagai pejabat umum pembuat akta. Setelah melewati ketentuan pertama Kemudian ditingkatkan berdasarkan ketentuan yang kedua yaitu menurut sanksi keperdataan Pasal 1365 Kitab Undang-Undang Hukum Perdata tentang wajib membayar ganti kerugian kepada para pihak yang dirugikan, dan kemudian dapat ditindaklanjuti. Berdasarkan ketentuan yang ketiga menurut Kitab Undang-Undang Hukum Pidana Pasal 264 ayat (1) yaitu pemalsuan surat yang diperberat sedangkan Pasal 266 ayat (1) yaitu pelaku penghadap/klien yang menyuruh Notaris melakukan untuk memasukkan keterangan palsu ke dalam akta otentik, dan bunyi dari masing-masing ayat (2) antara Pasal 264 dan 266 KUHP isinya sama yaitu tentang pembuatan akta dengan kesengajaan memakai akta seolah-olah isinya benar.

\subsection{Saran}

a. Pemerintah dan organisasi notaris memberikan pelatihan terhadap Notaris secara berkala agar tidak melakukan kesalahan yang fatal dimana membawa dampak pengaruh buruk yang dapat merugikan baik dari para pihak-pihak tertentu maupun diri sendiri dalam pembuatan akta otentik.

b. Pemerintah dan organisasi notaris dapat menindak secara tegas perbuatan Notaris dimana diduga melakukan pelanggaran kode etik profesi notaris yang dapat dikualifikasikan dalam tersangka tindak.

\section{Daftar Pustaka}

\section{Buku}

Habib Adjie, 2008, Hukum Notariat Di Indonesia Tafsiran Tematik Terhadap UU No. 30 Tahun 2004 tentang Jabatan Notaris, Bandung, Refika Aditama

Pengurus Pusat Ikatan Notaris Indonesia, 2008, Jati Diri Notaris Indonesia Dulu, Sekarang dan Dimasa Datang, Jakarta, PT. Gramedia Pustaka Utama

Satjipto Rahardjo, 2009, Penegakan Hukum Suatu Tinjauan Sosiologis, Genta Publishing, Yogyakarta. 


\section{Jurnal}

Amiruddin, Amiruddin, 2016 "Tanggung Jawab Pidana Notaris Dalam Kedudukannya Sebagai Pejabat Pembuat Akta”, Jurnal Media Hukum, Nomer 2 Vol 22, Januari 2016

Arif, Jufri, 2016 "Tinjauan Yuridis Pertanggungjawaban Pidana Notaris terhadap Pelanggaran Hukum Atas Akta", Legal Opinion, Nomer 5 Vol 2, April 2016

Habib Adjie,2 "Sanksi Pidana Notaris", Jurnal Renvoi, Nomor 10 Vol. 22 Tanggal 3 Maret 2005

\section{Makalah}

Habib Adjie, 2006 “Syarat Akta Otentik”, Majalah Renvoi, Nomor 3.39 Vol. IV, Agustus, 2006

\section{Regulasi}

Undang-Undang Nomor 30 Tahun 2004 tentang Jabatan Notaris (Lembaran Negara Republik Indonesia Tahun 2004 Nomor 117, Tambahan Lembaran Negara Republik Indonesia Nomor 4432)

Undang-undang Republik Indonesia Nomor 2 Tahun 2014 Tentang Perubahan atas Undangundang Nomor 30 Tahun 2004 Tentang Jabatan Notaris. Tambahan Lembaran Negara Republik Indonesia Tahun 4432

Kitab Undang-Undang Hukum Pidana (KUHP) pasal 263, 264, dan 266 Jo Pasal 55 ayat (1) ke1

\section{Website}

http://jogja.tribunnews.com/2017/04/12/notaris-ditahan-setelah-diduga-palsukan-akta-otentik, diakses pada hari Rabu tanggal 12 April 2017, pukul 16.00WIB 